\title{
Occurrence of antibiotics and antiretroviral drugs in source-separated urine, groundwater, surface water and wastewater in the peri-urban area of Chunga in Lusaka, Zambia
}

\author{
Elijah Ngumba',2, Anthony Gachanja², James Nyirenda ${ }^{3}$, Johanna Maldonado' and Tuula Tuhkanen ${ }^{1}$ \\ 'Department of Biological and Environmental Science, University of Jyvaskyla, PO Box 35, Fl- 40014 University of Jyvaskyla, Finland \\ ${ }^{2}$ Department of Chemistry, Jomo Kenyatta University of Agriculture and Technology, PO Box 62000-00200, Nairobi, Kenya \\ ${ }^{3}$ Department of Chemistry, The University of Zambia, PO Box 32379, Lusaka, Zambia
}

Recently, there has been an increased interest in bridging the knowledge gap in the occurrence and fate of pharmaceuticals in African urban water cycles. In this study, the occurrence of 7 antibiotics and 3 antiretrovirals in source-separated urine, groundwater, wastewater and surface water of the peri-urban area of Chunga in Lusaka, Zambia, was studied. In groundwater, the pharmaceuticals were only sporadically present with 4 antibiotics and 1 antiretroviral detected. The concentration of the antibiotics ranged from below limit of quantification ( $\angle L O Q)$ to $880 \mathrm{ng} / \mathrm{L}$, with sulfamethoxazole having the highest detection frequency of $42.3 \%$. In the surface water, a comparatively high concentration of pharmaceuticals was measured with concentrations ranging from $<\mathrm{LOQ}-11800 \mathrm{ng} / \mathrm{L}$ to $<\mathrm{LOQ}-49700 \mathrm{ng} / \mathrm{L}$ for antibiotics and antiretroviral drugs, respectively. Similarly, the concentration of antibiotics in wastewater treatment plant (WWTP) influent and effluent waters ranged from 100-33 $300 \mathrm{ng} / \mathrm{L}$ and 80-30 $040 \mathrm{ng} / \mathrm{L}$, respectively. The concentration of the antiretrovirals was also relatively high in the wastewater and ranged from $680-118970 \mathrm{ng} / \mathrm{L}$ and $1720-55760 \mathrm{ng} / \mathrm{L}$ in the influent and effluent, respectively. The concentration of the target analytes in source-separated urine were several orders of magnitude higher than in wastewater. Sulfamethoxazole, trimethoprim and lamivudine had the highest concentrations, of $7740 \mu \mathrm{g} / \mathrm{L}, 12800 \mu \mathrm{g} / \mathrm{L}$ and $10010 \mu \mathrm{g} / \mathrm{L}$, respectively. The high concentration detected in source-separated urine calls for precautionary measures to be undertaken when such urine is to be used as a fertilizer. However, urine source separation has a major advantage of pooling a significant proportion of excreted pharmaceuticals into small manageable volumes which can be effectively treated, minimizing environmental contamination. The high concentrations of antibiotics and antiretroviral drugs measured in this study necessitate creation of effective barriers to mitigate the possible environmental and human health risks.

\section{INTRODUCTION}

In recent years, the detection of pharmaceutical and personal care products in urban hydrological cycles at environmentally relevant concentrations has triggered increased attention and a considerable amount of literature relating to occurrence in different water systems have been published. Antibiotics and antiretroviral drugs are of a particular concern in this study due to their potential propagation of antimicrobial resistance and toxicity to sensitive aquatic organisms (Baran et al., 2011; Le-Minh et al., 2010; Baquero et al., 2008). It is well established from a variety of studies that one of the major routes of entry of pharmaceuticals into the environment is via discharges from wastewater treatment plants (WWTPs) (Kümmerer, 2009; Zhang et al., 2015). However, in areas with poor sanitation and/or no centralized WWTPs, infiltration from pit latrines, direct discharge of untreated wastewater and excreta to aquatic and terrestrial environments form a significant entry route of pharmaceuticals to the aquatic environment (Ngumba et al., 2016b; K'oreje et al., 2016; Rehman et al., 2013; Madikizela et al., 2017). To minimize environmental contamination and enhance nutrient recycling, alternative decentralized ecological sanitation systems have widely been explored (Simha and Ganesapillai, 2016; Udert et al., 2016; Richert et al., 2010). However, the source-separated urine may contain high concentrations of active pharmaceutical compounds and this can be an impediment to the utilization of source-separated urine in food crop production (Bischel et al., 2015; Jaatinen et al., 2016).

In this study, the occurrence of 7 antibiotics and 3 antiretroviral drugs in the peri-urban area of Chunga in Lusaka-Zambia was determined in groundwater, surface water, wastewater and sourceseparated urine. Zambia has an adult HIV/AIDS prevalence of $12.9 \%$ with 1.2 million people living with HIV of whom $63 \%$ are under antiretroviral treatment (United Nations Programme on HIV/AIDS, 2016; WHO, 2016b). In addition to HIV, there is a relatively high disease burden in the population leading to enhanced pharmaceutical consumption through prescription and selfmedication by over-the-counter drugs. Geologically, Lusaka lies on an aquifer formed by rocky schists of quartzite and marble (Nkhuwa, 2006) and the groundwater tables lack a protective cover, making them vulnerable to contamination (African Development Bank, 2015). A significant portion of the population relies on decentralized forms of sanitation systems posing a contamination risk to groundwater and surface water (Wamukwamba and Share, 2001). In addition, a large proportion

\section{CORRESPONDENCE}

Elijah Ngumba

EMAIL

engumba@jkuat.ac.ke

\section{DATES}

Received: 17 January 2019

Accepted: 31 March 2020

\section{KEYWORDS}

antibiotics

antiretrovirals

groundwater

source-separated urine

wastewater

\section{COPYRIGHT}

(c) The Author(s)

Published under a Creative

Commons Attribution 4.0

International Licence (CC BY 4.0) 
of the population relies on groundwater (shallow water wells and boreholes) for their domestic use.

The studied antibiotics include trimethoprim (TMP), sulfamethoxazole (SMX), ciprofloxacin (CIP), norfloxacin (NOR), tetracycline (TET), doxycycline (DOX) and amoxicillin (AMO); and the antiretroviral drugs were nevirapine (NVP), zidovudine (ZDV) and lamivudine (3TC). NVP, ZDV and 3TC are some of the commonly prescribed first-line antiretroviral drugs for people suffering from HIV/AIDS. In addition to the antiretroviral drugs, the antiretroviral therapy (ART) for most patients will include a fixed dose of co-trimoxazole (dose ratio of 5:1 sulfamethoxazole: trimethoprim) prophylaxis to prevent HIV-induced infections (WHO, 2016a).

Despite the high antibiotic and antiretroviral consumption, there are currently no data available on the occurrence of active pharmaceutical ingredients in the aquatic environment of the study area. This study aims at providing some insights into the concentrations of selected antibiotics and antiretroviral drugs in selected aquatic environments.

\section{MATERIALS AND METHODS}

\section{Description of the study area and sample collection}

The study area was in the peri-urban suburb of Chunga on the north-western side of Lusaka, Zambia (Fig. 1). Lusaka is situated on a watershed, and the western parts of the city, including the study area, drain into the Kafue River (Lusaka City Council and Environmental Council of Zambia, 2008). The region hosts the informal settlement of Madimba with limited established water supply or sewage network. As a result, the residents rely on shallow water wells and pit latrines for domestic water source and sanitation, respectively. Due to the high population density, most of the water wells are dug in close proximity to the pit latrines. The area also has a high groundwater table resulting in contamination of the aquifers, shallow water wells and boreholes (Kawanga and Sinkala, 2005; Lusaka Water and Sewerage Company, 2013). The study area also hosts one conventional trickling filter wastewater treatment plant (Chunga) and one non-conventional wastewater stabilization pond (Matero) wastewater treatment plant with limited functionality due to aging and lack of adequate maintenance (Brown et al., 2012). The wastewater facilities discharge their effluents into Chunga River, a tributary of Mwembeshi River (Wamukwamba and Share, 2001). The river flows through Chunga residential areas and the riverbank is lined with domestic housing units that discharge untreated domestic waste into the river. The local population uses the wastewater effluents and river waters for irrigation purposes. To minimize on local contamination and enhance nutrient recycling within Madimba area, there have been efforts to introduce dry sanitation by constructing urine-diverting dry toilets (UDDTs) (Chongo and Kawanga, 2015). The urine and faecal matter collected are stored for a period of 6 months before application as an agricultural fertilizer.

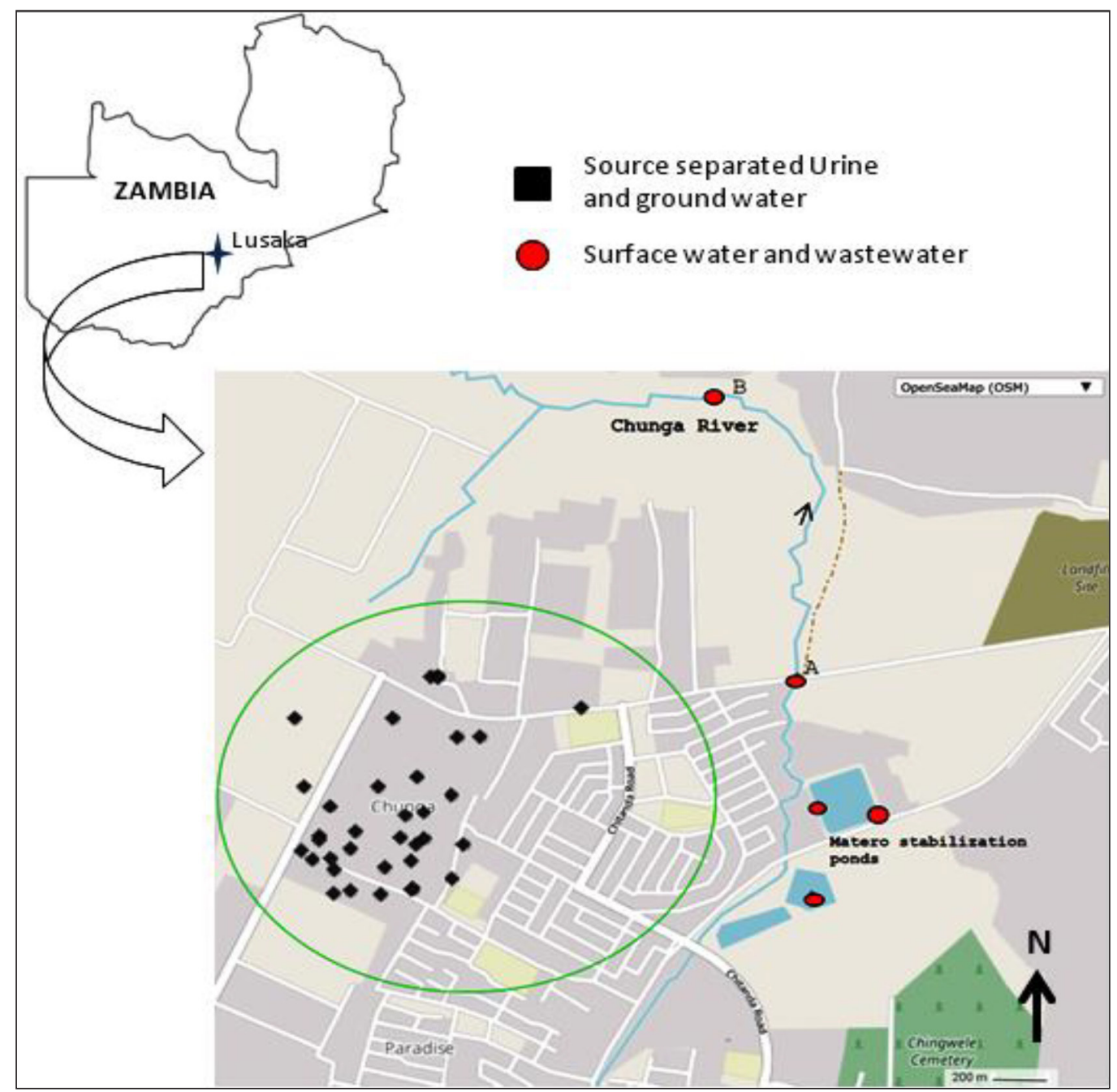

Figure 1. A map of Madimba and Chunga areas of Lusaka with the sample collection locations for source separated urine, groundwater, surface water and wastewater indicated. The map was constructed using GPS coordinates and GPS visualizer online tool (Available from http://www.gpsvisualizer.com) 
To study the occurrence of antibiotics and antiviral drugs in this locality, 21 groundwater samples were collected from protected and unprotected shallow wells and 5 from borehole wells. The surface water samples were collected from the Chunga River while the wastewater samples were taken from Matero wastewater stabilization ponds. Duplicate $600 \mathrm{~mL}$ grab water samples were collected in June 2016 using HDPE bottles that were rinsed with HPLC-grade methanol and stored in a refrigerator at $+4^{\circ} \mathrm{C}$ awaiting extraction within 1 week. The groundwater samples from shallow wells were drawn with water buckets and then transferred to sample bottles, apart from 2 samples that were taken directly into the sample bottles from the well. The borehole samples were collected through the taps or hoses. Ten duplicate urine grab samples were collected from Madimba and Chunga residential areas from UDDTs that were shared by more than one household. The samples were collected from the urineholding containers by pouring into $125 \mathrm{~mL}$ food-quality glass jars and transported on ice pack in a closed container and then extracted immediately on receipt in the laboratory.

\section{Analytical methods}

The methods for water sample preparation, extraction and analysis are as described in previous studies (Ngumba et al., 2016a; Ngumba et al., 2016b). In brief, water samples were first filtered through $47 \mathrm{~mm}$ GF/D $(2.7 \mu \mathrm{m})$ and GF/F $(0.7 \mu \mathrm{m})$ glass microfibre filters (Whatman, Maidstone, England), followed by addition of $40 \mu \mathrm{L}$ of $10 \mathrm{mg} / \mathrm{L}$ mixed internal standards (ISs) to $200 \mathrm{~mL}$ of filtered sample prior to SPE process. The samples were then loaded into Oasis HLB cartridges $(6 \mathrm{~mL}, 200 \mathrm{mg}$; Waters, Milford, USA) which had been conditioned with $3 \mathrm{~mL}$ methanol (EMSURE, analytical grade) and $3 \mathrm{~mL}$ distilled water, respectively. After loading, the cartridges were dried in vacuum for $10 \mathrm{~min}$ and washed with $5 \mathrm{~mL}$ ultrapure water followed by 5 $\mathrm{mL}$ of $2 \%$ methanol and then dried for a further $10 \mathrm{~min}$ before elution with $4 \mathrm{~mL} \mathrm{ACN} / \mathrm{MeOH},(1: 1 \mathrm{v} / \mathrm{v})$. The solvent was then evaporated in a stream of nitrogen at $40^{\circ} \mathrm{C}$. The sample was then re-constituted to $1 \mathrm{~mL}$ with acetonitrile/water $(20: 80 \mathrm{v} / \mathrm{v})$, and then filtered through a $0.2 \mu \mathrm{m}$ cellulose acetate syringe filter before injection into an LC-MS/MS system.

The sample preparation and extraction procedures for sourceseparated urine were modified from Pynnönen and Tuhkanen, (2014). SPE sample loading of the source-separated urine was carried out on-site using Oasis HLB cartridges $(3 \mathrm{~mL} 60 \mathrm{mg}$; Waters, Milford, USA) and $20 \mathrm{~mL}$ luer syringes. First, $40 \mu \mathrm{L}$ of $10 \mathrm{mg} / \mathrm{L}$ mixed ISs was added to $20 \mathrm{~mL}$ source-separated urine and then slowly passed through Oasis HLB cartridges which had been previously conditioned with $3 \mathrm{~mL}$ methanol (EMSURE, analytical grade) and $3 \mathrm{~mL}$ distilled water, respectively. After loading, cartridges were dried by blowing out excess moisture with an empty $20 \mathrm{~mL}$ syringe several times. Subsequent washing and elution SPE procedures were carried out in a similar way as for water samples.

Chromatographic separation and detection was carried out using Waters Quattro Micro LC-MS/MS system on a reversed phase C18 column. The mobile phase consisted of ultrapure water (A) and acetonitrile (B), both containing $0.1 \%(\mathrm{v} / \mathrm{v})$ formic acid. Mass spectrometric detection was operated in multiple reactions monitoring (MRM) and performed in the positive electrospray ionization (ESI+) mode.

\section{RESULTS AND DISCUSSION}

\section{Occurrence of the selected antibiotics and antiretroviral drugs in groundwater}

In total, 4 out of 7 antibiotics and 1 out of 3 antiretroviral drugs were detected in Chunga, shallow water wells and boreholes in the ng/L range. The detection frequency, range and median concentrations are presented in Table 1.

SMX had the highest detection frequency at $42.3 \%$ with a concentration range of nd- $660 \mathrm{ng} / \mathrm{L}$, which can be attributed to its high mobility in soil due to its weak sorption properties, in addition to being hydrolytically stable (Deng et al., 2016; Germer and Sinar, 2010). TMP had a detection frequency of $34.6 \%$ and was detected at relatively lower concentration (maximum of 140 $\mathrm{ng} / \mathrm{L}$ ) as compared with SMX. This could be partly due to its high distribution coefficient $\left(K_{\mathrm{d}}\right)$, and that the soil $\mathrm{pH}$ ranges in the study area of 4.02-5.56 (Chabala et al., 2014) are within TMP optimum sorption $\mathrm{pH}$ (4-6); hence, TMP is expected to be largely immobile (Kodešová et al., 2015). In addition, TMP is almost exclusively administered together with sulfonamides such as SMX in fixed ratio (1:5, TMP: SMX), leading to its lower mass load into the environment (WHO, 2016a). Among the fluoroquinolones (CIP and NOR), it was only CIP that was detected in a few wells, with a maximum concentration of 150 ng/L. Relatively lower detection was attributed to the high distribution coefficient $\left(K_{\mathrm{d}}\right)$ of fluoroquinolones in soil (Le-Minh et al., 2010) and relatively lower rate of consumption since CIP is a more expensive antibiotic. AMO is one of the most frequently prescribed antibiotics and has a relatively low distribution coefficient and is hence expected to be highly mobile in soil (Kim et al., 2012). However, the relatively low detection frequency in this study can be attributed to its high potential to undergo hydrolysis in the chemically susceptible $\beta$-lactam ring (Cha et al., 2006). The detected AMO in the few wells was attributed to possible contamination of the shallow water wells from the adjacent pit latrines.

Table 1. Summary of the detection frequency (\%) and concentrations for the selected antibiotics and antiretroviral drugs in the Chunga shallow wells, boreholes (ng/L)

\begin{tabular}{lccc}
\hline Pharmaceutical* & $\begin{array}{c}\text { Detection } \\
\text { frequency } \\
\text { (\%) }\end{array}$ & Range (ng/L) & $\begin{array}{c}\text { Median } \\
\text { (ng/L) }\end{array}$ \\
\hline TMP & 34.6 & nd $^{\mathrm{a}}-140$ & 60 \\
CIP & 19.2 & nd-150 & 90 \\
SMX & 42.3 & nd-660 & 100 \\
AMO & 11.5 & nd-880 & 760 \\
TET & 0 & nd & nd \\
NOR & 0 & nd & nd \\
DOX & 0 & nd & nd \\
3TC & 0 & nd & nd \\
ZDV & 0 & nd & nd \\
NVP & 38.5 & nd-410 & 150 \\
\hline
\end{tabular}

nd ${ }^{a}$ : not detected; *TMP: trimethoprim, SMX: sulfamethoxazole CIPciprofloxacin, NOR: norfloxacin, TET: tetracycline, DOX: doxycycline, AMO: amoxicillin NVP: nevirapine, ZDV: zidovudine, 3TC: lamivudine 
Tetracyclines (e.g., tetracycline and doxycycline) have high distribution coefficients in soils and are largely considered immobile (Kim et al., 2012). As a result, the compounds were not detected in any of the groundwater samples despite the relatively high concentrations detected in surface water and wastewater. The concentrations of antibiotics in groundwater were within one order of magnitude of that reported for other studies elsewhere. For example, the maximum concentration of SMX in Massachusetts-USA was 113 ng/L (Schaider et al., 2014) and $30 \mathrm{ng} / \mathrm{L}$ in Nairobi, Kenya (K'oreje et al., 2016). In India, Fick et al. (2009) reported $14000 \mathrm{ng} / \mathrm{L}$ of CIP in groundwater close to a pharmaceutical production company.

NVP was the only antiretroviral drug detected in the groundwater, with a maximum concentration $410 \mathrm{ng} / \mathrm{L}$ and detection frequency of $38.5 \%$. This might be due to NVP nonbiodegradability leading to persistence in the environment (Jain et al., 2013; Vaňková, 2010). The concentrations of NVP observed in this study were lower than reported for shallow water wells in Kenya (up to $1600 \mathrm{ng} / \mathrm{L}$ ) (K'oreje et al., 2016). However, in both the present study and the study by K'oreje et al. (2016), nevirapine mobility to groundwater is quite apparent. Despite the high concentrations measured for 3TC and ZDV in wastewater, surface water and source-separated urine; they were hardly detected in the groundwater. This was mostly attributed to strong adsorption to the acidic soils of the study area, as discussed earlier. K'oreje et al. (2016) made a similar finding for ZDV in Kenya where they measured high concentrations in surface water and significantly low concentrations in groundwater within the same vicinity.

\section{Occurrence of the selected antibiotics and antiretroviral drugs in surface water and wastewater}

A summary of the concentration of the antibiotics and antiretroviral drugs in the studied surface water and wastewaters is presented in Table 2. All the target analytes were detected in the study area with concentrations ranging from ng/L$\mu \mathrm{g} / \mathrm{L}$ levels. In the Matero wastewater stabilization ponds, the concentrations for individual antibiotics ranged from 100-33 $300 \mathrm{ng} / \mathrm{L}$. The hydrolytic retention times for the wastewater in the stabilization ponds were, however, not taken into consideration during sampling, and as such the removal efficiency for the studied pharmaceuticals in the stabilization ponds could not be estimated. SMX was the most dominant species in both the influent and effluent waters, with mean concentrations of
$33300 \pm 1890 \mathrm{ng} / \mathrm{L}$ and $30040 \pm 3420 \mathrm{ng} / \mathrm{L}$, respectively. Among the antiretroviral drugs, the concentration of individual drugs in the wastewaters ranged from 680-118 $970 \mathrm{ng} / \mathrm{L}$ and 1720 $55760 \mathrm{ng} / \mathrm{L}$ in the aerobic pond influent and effluent waters, respectively. 3TC was the most dominant antiretroviral in the effluent with a mean concentration of $55760 \pm 5480 \mathrm{ng} / \mathrm{L}$, followed by ZDV and NVP with mean concentrations of 37140 $\pm 2560 \mathrm{ng} / \mathrm{L}$ and $1720 \pm 250 \mathrm{ng} / \mathrm{L}$, respectively.

The significantly high concentrations of antibiotics and antiretroviral drugs in the wastewater were attributed to the high prevalence of diseases, especially HIV/AIDS, and inefficient wastewater treatment. The HIV prevalence in Zambia stood at $12.9 \%$ of the adult population by 2015 , the majority of whom were under antiretroviral therapy comprising of at least three antiviral drugs and co-trimoxazole (sulfamethoxazole/ trimethoprim in the ratio 5:1) (United Nations Programme on HIV/AIDS, 2016; WHO, 2016b). In addition, Brown et al. (2012) have reported that the wastewater stabilization ponds in Lusaka had limited functionality due to factors such as sludge accumulation and erosion shortening the hydraulic retention time. The concentrations measured in the wastewater for a majority of compounds and medications were significantly higher than reported elsewhere. For example, the maximum concentration was $1309.5 \mathrm{ng} / \mathrm{L}$ for SMX in Bolivia (Archundia et al., 2017); $150 \mathrm{ng} / \mathrm{L}, 31070 \mathrm{ng} / \mathrm{L}, 110 \mathrm{ng} / \mathrm{L}, 2080 \mathrm{ng} / \mathrm{L}$, for TMP, 3TC, ZDV and NVP, respectively, in Kenya (K'oreje et al., 2016); $620 \mathrm{ng} / \mathrm{L}$ for TET in Hong Kong/China (Gulkowska et al., 2008); and $50 \mathrm{ng} / \mathrm{L}$ for AMO in Australia (Watkinson et al., 2007).

In the surface waters and among the antibiotics, the concentration ranged from <LOQ-11 $800 \mathrm{ng} / \mathrm{L}$. SMX had the highest concentration of $11800 \pm 1200 \mathrm{ng} / \mathrm{L}$ at sampling site A of Chunga River while NOR was not detected at the two sampling sites. The concentration of the antiretrovirals ranged from $<\mathrm{LOQ}-49700 \mathrm{ng} / \mathrm{L}$. 3TC had the highest concentration of $49700 \pm 4000 \mathrm{ng} / \mathrm{L}$ followed by ZDV and NVP with concentrations of $9670 \pm 1290 \mathrm{ng} / \mathrm{L}$ and $220 \pm 30 \mathrm{ng} / \mathrm{L}$, respectively. The three antiretroviral drugs constitute the first line daily dose antiretroviral regimen for people living with HIV. The large variation in the concentration can be attributed to their differences relating to excretion of the drugs in the unchanged form. In this case, approximately $70 \%, 20 \%$ and $2.7 \%$ of 3TC, ZDV and NVP, respectively, are excreted from the body in the unchanged form (Harlass, 1996; Kumar et al., 2006;

Table 2. Concentrations of selected antibiotics and antiretroviral drugs in surface water of Chunga River and WWTP influent and effluent samples in $\mathrm{ng} / \mathrm{L}$

\begin{tabular}{|c|c|c|c|c|}
\hline \multirow{2}{*}{ Pharmaceutical* } & \multicolumn{2}{|c|}{ Chunga River } & \multicolumn{2}{|c|}{ Wastewater } \\
\hline & Site A & Site B & Aerobic pond Influent & Aerobic pond Effluent \\
\hline TMP & $2410 \pm 20^{a}$ & $510 \pm 50$ & $32670 \pm 1570$ & $1770 \pm 160$ \\
\hline CIP & $400 \pm 90$ & $540 \pm 70$ & $740 \pm 80$ & $230 \pm 30$ \\
\hline SMX & $11800 \pm 1200$ & $7810 \pm 740$ & $33300 \pm 1890$ & $30040 \pm 3420$ \\
\hline AMO & $2500 \pm 660$ & $3410 \pm 440$ & $3270 \pm 690$ & $5580 \pm 1880$ \\
\hline TET & $2200 \pm 700$ & $4220 \pm 740$ & $220 \pm 20$ & $4590 \pm 540$ \\
\hline NOR & $n d^{b}$ & nd & $100 \pm 20$ & $80 \pm 20$ \\
\hline DOX & $2730 \pm 610$ & $3260 \pm 590$ & $4490 \pm 810$ & $5280 \pm 1190$ \\
\hline 3TC & $49700 \pm 4000$ & $42630 \pm 3660$ & $118970 \pm 9450$ & $55760 \pm 5480$ \\
\hline ZDV & $1280 \pm 400$ & $9670 \pm 1290$ & $66590 \pm 4650$ & $37140 \pm 2560$ \\
\hline NVP & $210 \pm 30$ & $220 \pm 30$ & $680 \pm 60$ & $1720 \pm 250$ \\
\hline
\end{tabular}

aMean \pm SD (based on duplicate samples); $n d^{b}$ : not detected; *TMP: trimethoprim, SMX: sulfamethoxazole CIP-ciprofloxacin, NOR: norfloxacin, TET: tetracycline, DOX: doxycycline, AMO: amoxicillin NVP: nevirapine, ZDV: zidovudine, 3TC: lamivudine 
Riska et al., 1999). The high concentration of antibiotics and antiretroviral drugs measured in this study can be attributed to the direct discharge of untreated domestic waste from the adjacent informal settlement of Madimba and discharges from the Chunga and Matero wastewater treatment plants.

The concentration of antibiotics and antiretroviral drugs in the surface water were within one order of magnitude relative to studies done in South Africa, Ghana, Kenya and Mozambique. For instance, the concentration ranged from 511-53 $828 \mathrm{ng} / \mathrm{L}$ for SMX, <LOQ-11 383 for TMP and <LOQ-465 ng/L for TET in Mozambique, Kenya and Ghana, respectively (Segura et al., 2015); <LOQ-167 $000 \mathrm{ng} / \mathrm{L}$ for 3TC and $<\mathrm{LOQ}-17000 \mathrm{ng} / \mathrm{L}$ for ZDV in Kenya (K'oreje et al., 2016); <LOQ-177 ng/L for NVP in South Africa (Wood et al., 2015). However, the concentrations were several orders of magnitude higher when compared with most studies in developed countries. For example, the concentration of antiretroviral drugs in some studies of surface water in Germany and Belgium were all $<200 \mathrm{ng} / \mathrm{L}$ (Vergeynst et al., 2015; Prasse et al., 2010). Segura et al. (2015) pointed out that there is a direct relationship between the occurrence of pharmaceuticals in surface water and economic strength of a country due to the higher vulnerability to infectious deseases in lower-income countries, self-medication, availability of cheap over-the-counter drugs as well as inadequate wastewater collection and treatment facilities. The concentrations measured in this study and other recent studies in East Africa, South Africa and West Africa points to a more serious wide-scale contamination of urban hydrological cycles with antibiotics and antiretroviral drugs in the entire region.

\section{Occurrence of the selected antibiotics and antiretroviral drugs in source-separated urine}

All the studied antibiotics were detected in the studied sourceseparated urine with frequencies of $40-100 \%$ at $\mu \mathrm{g} / \mathrm{L}-\mathrm{mg} / \mathrm{L}$ levels. As shown in Table 3, TMP and DOX were detected in all the samples while TET and SMX were detected in 4 out of 10 samples. The highest measured antibiotic concentration was for TMP (12 $800 \mu \mathrm{g} / \mathrm{L})$, followed by SMX (7 $740 \mu \mathrm{g} / \mathrm{L})$, CIP (660 $\mu \mathrm{g} / \mathrm{L}), \operatorname{AMO}(310 \mu \mathrm{g} / \mathrm{L}), \mathrm{DOX}(20 \mu \mathrm{g} / \mathrm{L}), \mathrm{NOR}(5.3 \mu \mathrm{g} / \mathrm{L})$ and TET $(2.8 \mu \mathrm{g} / \mathrm{L})$. The concentration of TMP and SMX were particularly elevated in the urine samples because of their regular use in treatment of bacterial infections and are particularly prescribed for daily use to prevent opportunistic infections in patients with HIV (Bartlett, 2004). Recent studies on pharmaceuticals in source-separated urine in eThekwini, South Africa (Bischel et al., 2015) measured maximum concentrations of $6800 \mu \mathrm{g} / \mathrm{L}$ for SMX, which is comparable with the present study. The occurrence of antiretroviral drugs in urine varied considerably with 3TC detected at the highest frequency (100\%) and concentration $(10010 \mu \mathrm{g} / \mathrm{L})$ while NVP was detected in one sample and ZDV was below the limit of quantification. The variation in the concentrations of antiretroviral drugs in urine can be attributed to the consumption; in addition, some of the compounds are excreted largely as metabolites shown in Table 4 .

Although the most critical concern associated with the use of source-separated urine emanates from the presence of diseasecausing pathogens, the storage of urine for 6 months at $20^{\circ} \mathrm{C}$ deactivates much of the pathogens (WHO, 2006). However, it has been shown that minimum pharmaceutical reduction is realized during the storage (Bischel et al., 2015; Jaatinen et al., 2016; Koch, 2015). For example, Bischel et al. (2015) studied the fate of 12 pharmaceutical compounds during the storage of source-separated urine and found that 11 out of 12 compounds did not degrade to a significant extent during the storage period. The findings are corroborated by bench-scale studies by Jaatinen et al. (2016) who found reduction of $25.6 \%, 51.5 \%, 75.6 \%$, $24.0 \%, 23.7 \%$ and $51.1 \%$ for NVP, ZDV, 3TC, SMX, and TMP, respectively, after 6 months of storage.

The recalcitrant nature of pharmaceuticals in source-separated urine becomes an impediment to its direct application as a fertilizer with possible negative ramifications including uptake by plants as well as effects on soil microbial communities (Kümmerer, 2003; Li et al., 2013). Thus, in areas with high disease prevalence and pharmaceutical consumption, the use of source-separated urine as a fertilizer may pose considerable ecological and human health risks.

\section{CONCLUSIONS}

The main goal of this study was to determine the occurrence of 10 pharmaceuticals - 7 antibiotics and 3 antiretroviral drugs - in groundwater, surface water, wastewater and sourceseparated urine in Chunga area of Lusaka, Zambia. The results of this study show that all the analysed sample sets had environmentally relevant concentrations of the antibiotics

Table 3. Summary of the detection frequency (\%) and concentrations for the selected antibiotics and antiretroviral drugs in the sourceseparated urine in $\mu \mathrm{g} / \mathrm{L}$

\begin{tabular}{|c|c|c|c|c|c|}
\hline Pharmaceutical* & $\begin{array}{c}\text { Detection } \\
\text { frequency } \%\end{array}$ & Range & Median & Mean & $\begin{array}{c}\text { Excretion rate } \\
\text { as unchanged } \\
\text { compound } \\
(\%)^{b}\end{array}$ \\
\hline TMP & 100 & $0.7-12800$ & 4.9 & 2199 & $80-90$ \\
\hline CIP & 90 & $n d^{\mathrm{a}}-660$ & 5.2 & 78.1 & 80 \\
\hline SMX & 40 & nd-7 740 & 1660 & 2430 & $15-25$ \\
\hline AMO & 80 & nd-310 & 13 & 58.1 & $60-80$ \\
\hline TET & 40 & nd-2.8 & 0.9 & 1.4 & $80-90$ \\
\hline NOR & 90 & nd-5.3 & 2.8 & 2.6 & 60 \\
\hline DOX & 100 & $2-20$ & 13.8 & 13.1 & 70 \\
\hline $3 \mathrm{TC}$ & 100 & $1.9-10010$ & 20 & 1670 & 70 \\
\hline ZDV & 0 & nd-nd & $\mathrm{Nd}$ & nd & $15-20$ \\
\hline NVP & 10 & nd-5 & 5 & 5 & 2.7 \\
\hline
\end{tabular}

nd ${ }^{a}$ : not detected ${ }^{b}$ (Radke et al., 2009; Kasprzyk-Hordern et al., 2009; Harlass, 1996; Straub, 2013; Jjemba, 2006; Kumar et al., 2006; Riska et al., 1999) *TMP: trimethoprim, SMX: sulfamethoxazole CIP-ciprofloxacin, NOR: norfloxacin, TET: tetracycline, DOX: doxycycline, AMO: amoxicillin NVP: nevirapine, ZDV: zidovudine, 3TC: lamivudine 
and antiretroviral drugs at concentration levels of up to several $\mathrm{mg} / \mathrm{L}$. Generally, pharmaceuticals associated with HIV treatment were detected at elevated concentrations. The high concentration measured in surface waters was attributed to direct discharge of untreated domestic waste as well as effluents from wastewater treatment plants. The high concentration of the pharmaceuticals in urine is an indicator that source separation has an advantage of pooling the majority of the pharmaceutical residues into small volumes which can effectively be treated, enabling minimization of environmental exposure. Although the detected concentrations of antibiotics and antiretroviral drugs in the sampled groundwater were low, the presence of transformation products is highly likely. This is because pharmaceutical residues are continuously being discharged into the environment, mostly into the pit latrines which are a major form of sanitation in the study area. Comprehensive fate studies are thus necessary in order to minimize ecological and human health risks. In addition, as precautionary measures, proper water treatment options should be explored since long-term sub-lethal exposure effects are largely unknown. The results of this study are consistent with the data obtained in other regions with similar economic and disease burdens. To ensure that both human health and the environment are protected, efforts to improve the centralized and decentralized wastewater management ought to be made as a priority. Preventing the leaching of pharmaceuticals into water sources from pit latrines and septic tanks through source separation and use of excreta as fertilizer for non-edible crops may be one viable option. Further research on possible pharmaceutical uptake by crops deriving nutrients from source-separated urine is recommended.

\section{ACKNOWLEDGMENTS}

This work was financially supported by the University of Jyväskylä Doctoral Program in Biological and Environmental Science and Maa- ja vesitekniikan tuki ry and University of Jyväskylä bilateral student exchange travel scholarship. The authors are also thankful to the scientists from the University of Zambia, Department of Chemistry, for the support during sample preparation as well as to Mrs Patricia Sakala from the International Link Office for kindly providing support and contacts. We would also like to thank the personnel of the non-governmental organizations Network for Environmental Concerns and Solutions, Obed Kawanga, Lydia Chibambo and Noah Chongo, as well as Sari Huuhtanen from the Global Dry Toilet Association of Finland for providing their vital support to the sampling period of this study, and José Maldonado for assistance during sample collection.

\section{REFERENCES}

AFRICAN DEVELOPMENT BANK (2015) Lusaka Sanitation Program - Climate Resilient Sustainable Infrastructure. African Development Bank, Lusaka.

ARCHUNDIA D, DUWIG C, LEHEMBRE F, CHIRON S, MOREL M-C, PRADO B, BOURDAT-DESCHAMPS M, VINCE E, AVILES GF and MARTINS JMF (2017) Antibiotic pollution in the Katari subcatchment of the Titicaca Lake: Major transformation products and occurrence of resistance genes. Sci. Total Environ. 576 671-682. https://doi.org/10.1016/j.scitotenv.2016.10.129.

BAQUERO F, MARTÍNEZ JL and CANTÓN R (2008) Antibiotics and antibiotic resistance in water environments. Curr. Opin. Biotechnol. 19 (3) 260-265. https://doi.org/10.1016/j.copbio.2008.05.006.

BARAN W, ADAMEK E, ZIEMIAŃSKA J and SOBCZAK A (2011) Effects of the presence of sulfonamides in the environment and their influence on human health. J. Hazardous Mater. 196 1-15. https:// doi.org/10.1016/j.jhazmat.2011.08.082.

BARTLETT JG (2004) A Guide to Primary Care of People with HIV / AIDS. Department of Health and Human Services, Rockville. $167 \mathrm{pp}$.
BISCHEL HN, ÖZEL DUYGAN BD, STRANDE L, MCARDELL CS, UDERT KM and KOHN T (2015) Pathogens and pharmaceuticals in source-separated urine in eThekwini, South Africa. Water Res. 85 57-65. https://doi.org/10.1016/j.watres.2015.08.022.

BROWN N, NEMCIK J and PETTI M (2012) Sanitation Master Plan for Lusaka, Zambia. Proceedings of the Water Environment Federation, Alexandria, VA, 2012 (13) 3266-3289. https://doi. org/10.2175/193864712811726969.

CHA JM, YANG S and CARLSON KH (2006) Trace determination of $\beta$-lactam antibiotics in surface water and urban wastewater using liquid chromatography combined with electrospray tandem mass spectrometry. J. Chromatogr. A 1115 (1-2) 46-57. https://doi. org/10.1016/j.chroma.2006.02.086.

CHABALA L, MULOLWA A and LUNGU O (2014) Mapping the spatial variability of soil acidity in Zambia. Agronomy 4 (4) 452-461. https:// doi.org/10.3390/agronomy4040452.

CHONGO N and KAWANGA C (2015) Inclusive stakeholder participation for sustaining dry sanitation solution in periurban areas: A Madimba community experience, Zambia. In: 5th International Dry Toilet Conference, 19-22 August 2015, Tampere, Finland.

DENG W, LI N, ZHENG H and LIN H (2016) Occurrence and risk assessment of antibiotics in river water in Hong Kong. Ecotoxicol. Environ. Saf. 125 121-7. https://doi.org/10.1016/j.ecoenv.2015.12.002.

FICK J, SODERSTROM H, LINDBERG RH, PHAN C, TYSKLIND M and LARSSON JDG (2009) Contamination of surface, ground, and drinking water from pharmaceutical production. Environ. Toxicol. Chem. 28 (12) 2522-2527. https://doi.org/10.1897/09-073.1.

GERMER J and SINAR E (2010) Pharmaceutical consumption and residuals potentially relevant to nutrient cycling in Greater Accra, Ghana. J. Agric. Rural Dev. Tropics Subtropics 111 (1) 41-53.

GULKOWSKA A, LEUNG HW, SO MK, TANIYASU S, YAMASHITA N, YEUNG LWY, RICHARDSON BJ, LEI AP, GIESY JP and LAM PKS (2008) Removal of antibiotics from wastewater by sewage treatment facilities in Hong Kong and Shenzhen, China. Water Res. 42 (1-2) 395-403. https://doi.org/10.1016/j.watres.2007.07.031.

HARLASS FE (1996) The pharmacology of zidovudine. Primary Care Update OB/GYNS 3 (2) 58-62. https://doi.org/10.1016/ S1068-607X(95)00058-Q.

JAATINEN ST, PALMROTH MRT, RINTALA JA and TUHKANEN TA (2016) The effect of urine storage on antiviral and antibiotic compounds in the liquid phase of source-separated urine. Environ. Technol. 37 (17) 2189-2198. https://doi.org/10.1080/09593330.2016. 1144799.

JAIN S, KUMAR P, VYAS RK, PANDIT P and DALAI AK (2013) Occurrence and removal of antiviral drugs in environment: a review. Water, Air, Soil Pollut. 224 (2) 1410. https://doi.org/10.1007/ s11270-012-1410-3.

JJEMBA PK (2006) Excretion and ecotoxicity of pharmaceutical and personal care products in the environment. Ecotoxicol. Environ. Saf. 63 (1) 113-130. https://doi.org/10.1016/j.ecoenv.2004.11.011.

K'OREJE KO, VERGEYNST L, OMBAKA D, DE WISPELAERE P, OKOTH M, VAN LANGENHOVE H and DEMEESTERE K (2016) Occurrence patterns of pharmaceutical residues in wastewater, surface water and groundwater of Nairobi and Kisumu city, Kenya. Chemosphere 149 238-244. https://doi.org/10.1016/j. chemosphere.2016.01.095.

KASPRZYK-HORDERN B, DINSDALE RM and GUWY AJ (2009) The removal of pharmaceuticals, personal care products, endocrine disruptors and illicit drugs during wastewater treatment and its impact on the quality of receiving waters. Water Res. 43 (2) 363-380. https://doi.org/10.1016/j.watres.2008.10.047.

KAWANGA OC and SINKALA A (2005) Madimba peri-urban integrated sanitation project: A zambian experience. In: 31st WEDC International Conference, 31 October-4 November 2005, Kampala, Uganda.

KIM Y, LIM S, HAN M and CHO J (2012) Sorption characteristics of oxytetracycline, amoxicillin, and sulfathiazole in two different soil types. Geoderma 185-186 97-101. https://doi.org/10.1016/j. geoderma.2012.03.016.

KOCH A (2015) Fate of pharmaceuticals and perfluoroalkyl substances during source separated wastewater treatment. Swedish University of Agricultural Sciences, Uppsala. 
KODEŠOVÁ R, GRABIC R, KOČÁREK M, KLEMENT A, GOLOVKO O, FÉR M, NIKODEM A and JAKŠÍK O (2015) Pharmaceuticals sorptions relative to properties of thirteen different soils. Sci. Total Environ. 511 435-443. https://doi.org/10.1016/j. scitotenv.2014.12.088.

KUMAR AKH, RAMACHANDRAN G, KUMAR P, KUMARASWAMI V and SWAMINATHAN S (2006) Can urine lamivudine be used to monitor antiretroviral treatment adherence? J. Int. AIDS Soc. 8 (4) $1-6$.

KÜMMERER K (2003) Significance of antibiotics in the environment. J. Antimicrob. Chemotherapy 52 (June) 5-7. https://doi.org/10.1093/ jac/dkg293.

KÜMMERER K (2009) Antibiotics in the aquatic environment - A review - Part I. Chemosphere 75 (4) 417-434. https://doi org/10.1016/j.chemosphere.2008.11.086.

LE-MINH N, KHAN SJ, DREWES JE and STUETZ RM (2010) Fate of antibiotics during municipal water recycling treatment processes. Water Res. 44 (15) 4295-4323. https://doi.org/10.1016/j. watres.2010.06.020.

LI X, YU H, XU S and HUA R (2013) Uptake of three sulfonamides from contaminated soil by pakchoi cabbage. Ecotoxicol. Environ. Saf. 92 297-302. https://doi.org/10.1016/j.ecoenv.2013.03.010.

LUSAKA CITY COUNCIL AND ENVIRONMENTAL COUNCIL OF ZAMBIA (2008) Lusaka City State of Environment Outlook Report. Lusaka.

LUSAKA WATER AND SEWERAGE COMPANY (2013) Lusaka Water Supply, Sanitation and Drainage (LWSSD) Project. Lusaka Water and Sewerage Company, Lusaka.

MADIKIZELA LM, TAVENGWA NT and CHIMUKA L (2017) Status of pharmaceuticals in African water bodies: Occurrence, removal and analytical methods. J. Environ. Manage. 193 211-220. https:// doi.org/10.1016/j.jenvman.2017.02.022.

NGUMBA E, KOSUNEN P, GACHANJA A and TUHKANEN T (2016a) A multiresidue analytical method for trace level determination of antibiotics and antiretroviral drugs in wastewater and surface water using SPE-LC-MS/MS and matrix-matched standards. Anal. Meth. 8 (37) 6720-6729. https://doi.org/10.1039/C6AY01695B.

NGUMBA E, GACHANJA A and TUHKANEN T (2016b) Occurrence of selected antibiotics and antiretroviral drugs in Nairobi River Basin Kenya. Sci. Total Environ. 539 206-213. https://doi.org/10.1016/j. scitotenv.2015.08.139.

NKHUWA DCW (2006) Groundwater quality assessments in the John Laing and Misisi areas of Lusaka. In: Xu Y and Usher B (eds.) Groundwater Pollution in Africa. Taylor \& Francis Group, London. https://doi.org/DOI: 10.1201/9780203963548.ch21

PRASSE C, SCHLÜSENER MP, SCHULZ R and TERNES T (2010) Antiviral drugs in wastewater and surface waters: A new pharmaceutical class of environmental relevance? Environ. Sci. Technol. 44 (5) 1728-1735. https://doi.org/10.1021/es903216p.

PYNNÖNEN ST and TUHKANEN T (2014) Simultaneous detection of three antiviral and four antibiotic compounds in source-separated urine with liquid chromatography. J. Sep. Sci. 37 (3) 219-227. https:// doi.org/10.1002/jssc. 201300492 .

RADKE M, LAUWIGI C, HEINKELE G, MÚRDTER TE and LETZEL M (2009) Fate of the antibiotic sulfamethoxazole and its two major human metabolites in a water sediment test. Environ. Sci. Technol. 43 (9) 3135-3141. https://doi.org/10.1021/es900300u.

REHMAN MSU, RASHID N, ASHFAQ M, SAIF A, AHMAD N and HAN JI (2013) Global risk of pharmaceutical contamination from highly populated developing countries. Chemosphere 138 10451055. https://doi.org/10.1016/j.chemosphere.2013.02.036.

RICHERT A, GENSCH R, DAGERSKOG L and JÖNSSON H (2010) Practical Guidance on the Use of Urine in Crop Production. Stockholm Environment Institute, Stockholm. 69 pp.

RISKA P, LAMSON M, MACGREGOR T, SABO J, HATTOX S, PAV
J and KEIRNS J (1999) Disposition and biotransformation of the antiretroviral drug nevirapine in humans. Drug Metab. Disposition 27 (8) 895-901.

SCHAIDER LA, RUDEL RA, ACKERMAN JM, DUNAGAN SC and BRODY JG (2014) Pharmaceuticals, perfluorosurfactants, and other organic wastewater compounds in public drinking water wells in a shallow sand and gravel aquifer. Sci. Total Environ. 468-469 384393. https://doi.org/10.1016/j.scitotenv.2013.08.067.

SEGURA PA, TAKADA H, CORREA JA, EL SAADI K, KOIKE T, ONWONA-AGYEMAN S, OFOSU-ANIM J, SABI EB, WASONGA OV, MGHALU JM and co-authors (2015) Global occurrence of anti-infectives in contaminated surface waters: Impact of income inequality between countries. Environ. Int. 80 89-97. https://doi. org/10.1016/j.envint.2015.04.001.

SIMHA P and GANESAPILLAI M (2016) Ecological sanitation and nutrient recovery from human urine: How far have we come? A review. Sustainable Environ. Res. 27 (3) 107-116. https://doi. org/10.1016/j.serj.2016.12.001.

STRAUB J (2013) An environmental risk assessment for human-use trimethoprim in European surface waters. Antibiotics 2 (1) 115-162. https://doi.org/10.3390/antibiotics2010115.

UDERT KM, ETTER B and GOUNDEN T (2016) Promoting sanitation in South Africa through nutrient recovery from urine. GAIA Ecol. Perspect. Sci. Soc. 25 (3) 194-196. https://doi.org/10.14512/ gaia.25.3.12.

UNITED NATIONS PROGRAMME ON HIV/AIDS (2016) Prevention GAP report UNAIDS 2016. United Nations Programme on HIV/ AIDS, Geneva.

VAŇKOVÁ M (2010) Biodegradability analysis of pharmaceuticals used in developing countries; screening with OxiTop ${ }^{\circledR}$ - C 110. Bachelors thesis, Tampere University of Applied Sciences, Tampere. 73 pp.

VERGEYNST L, HAECK A, DE WISPELAERE P, VAN LANGENHOVE $\mathrm{H}$ and DEMEESTERE K (2015) Multi-residue analysis of pharmaceuticals in wastewater by liquid chromatographymagnetic sector mass spectrometry: Method quality assessment and application in a Belgian case study. Chemosphere 119 S2-S8. https:// doi.org/10.1016/j.chemosphere.2014.03.069.

WAMUKWAMBA CK and SHARE W (2001) Sewage waste management in the city of Lusaka. In: Proceedings of $27^{\text {th }}$ WEDC International Conference, 20-24 August 2001, Lusaka, Zambia.

WATKINSON AJ, MURBY EJ and COSTANZO SD (2007) Removal of antibiotics in conventional and advanced wastewater treatment: implications for environmental discharge and wastewater recycling. Water Res. 41 (18) 4164-76. https://doi.org/10.1016/j. watres.2007.04.005.

WOOD TP, DUVENAGE CSJ and ROHWER E (2015) The occurrence of anti-retroviral compounds used for HIV treatment in South African surface water. Environ. Pollut. 199 235-243. https://doi. org/10.1016/j.envpol.2015.01.030.

WHO (WORLD HEALTH ORGANIZATION) (2006) Guidelines for the Safe use of Wastewater, Excreta and Greywater. Volume 4. World Health Organization, Geneva. 68 pp. https://doi.org/10.1007/ s13398-014-0173-7.2

WHO (WORLD HEALTH ORGANIZATION) (2016a) Consolidated guidelines on the use of antiretroviral drugs for treating and preventing HIV infection: recommendations for a public health approach. ( $2^{\text {nd }}$ edn). World Health Organization, Geneva.

WHO (WORLD HEALTH ORGANIZATION) (2016b) Prevent HIV, Test and Treat All Progress Report 2016. World Health Organization, Geneva. 64 pp.

ZHANG H, DU M, JIANG H, ZHANG D, LIN L, YE H and ZHANG $\mathrm{X}$ (2015) Occurrence, seasonal variation and removal efficiency of antibiotics and their metabolites in wastewater treatment plants, Jiulongjiang River Basin, South China. Environ. Sci. Process. Impacts 17 (1) 225-234. https://oi.org/10.1039/C4EM00457D 